The Murchison Fund to Mr. Stephen Henry Straw, in recognition of the value of his investigations into Silurian stratigraphy and the relations of the Silurian and Devonian rocks in the Welsh borders and the Midlands.

The Lyell Fund to Mr. James Frederick Jackson for his contributions to the palaeontology of the rocks of the Isle of Wight, and Dr. Mabel Elizabeth Tomlinson, for her researches on the Glacial and post-Glacial deposits of the Midlands.

\title{
CORRESPONDENCE.
}

\section{THE NAME OF A FOSSIL CAT.FISH.}

SIR,-Recently I published a description of the skull of a cat-fish from the early Eocene beds of North-west Nigeria, referring it to a new genus, which I named Macronoides, owing to its resemblance in certain respects to the living Macrones Duméril ("Fossil Fishes of Sokoto Province," Bull. Surv. Nigeria, Bulletin 14, 1934, p. 53). I now find that this name has already been used for a living cat-fish of the same family (Hora, Rec. Indian Museum, Bull. 22, 1921, p. 179), and I propose, therefore, to rename the fossil Eomacrones.

ERrol I. WhIte.

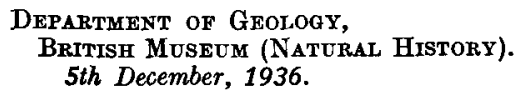

\section{THE AGE OF THE HOWTH ROCKS.}

SIR,-In the issue of this Magazine for December, 1936 (p. 546), the expression "Greenly proposes a pre-Cambrian age" seems to convey an impression of a more definite opinion than $I$ have ever held. Perhaps the word "suggests" would convey my meaning better. My words in The Geology of Anglesey (p. 896) were: ". . Howth Hill by Dublin, where there is little doubt that we can recognize"the Gwna Beds." Could I re-edit that book I think that I would substitute "where it would appear that".

The suggestion of the author that the Gwna quartzites may possibly be of aeolian origin is very welcome, and may prove illuminating, but will need to be considered in connection with all the features of that heterogeneous group.

Edward Greenly.

Bangor, North Wales.

7 th December, 1936. 